\title{
Hindrances To Effective Delivery Of Guidance And Counselling Services Towards Enhancing Discipline Among Students In OlokurtoDivision, Narok County Kenya
}

\author{
Kamundia I. Robert, Dr. Thomas N. Kinga \\ Maasai Mara University P.O. Box 861 - 20500, Narok \\ Kenyatta University P.O. Box 43844 - 00100 Nairobi
}

\begin{abstract}
While education is expected to change the behaviour of learners positively by moulding them into self-respecting and self- reliant individuals, discipline related issues have been at the fore of educational debates as students encounter challenges associated with adolescence. Cases of truancy, drug abuse, immorality, destruction of property and loss of life, are however, indicators of the existence of a conflict between educational aims and discipline among secondary school students despite the provision of guidance and counselling services in schools. The objective of study was to establish the hindrances to effective delivery of guidance and counselling services towards enhancing discipline among secondary school students in Olokurto Division, Narok County, Kenya. Descriptive survey design was employed in the study and questionnaires used obtain data from respondents. Person centred theory advanced by Carl Rogers guided the study. The study population comprised 861 students, 12 teacher counsellors and 6 deputy principals drawn from the six public secondary schools in the division. Stratified and simple random sampling techniques were employed to sample 129 students for the study. Schools, deputy principals and teacher counsellors in the division were purposively sampled. Using test-retest method, the instruments yielded a reliability coefficient of $r=0.76$, thus acceptedfor the study. Data were analyzed using the SPSS software version 20.0 and presented in tables, charts, graphs, means, frequencies and percentages. The study established that there was no guidance and counselling policy, teacher counsellors had very low training levels and heavy workloads, poorly established guidance and counselling departments that lacked resources and facilities. The study recommends training of counselling personnel, reduction of teaching load for counsellors and strengthening of guidance and counselling departments by providing resources and facilities.Findings and recommendations of this study, if implemented will be useful to policy makers in the Ministry of Education, heads of secondary schools, counselling personnel and students through improved services from more informed teacher counsellors.
\end{abstract}

Key words:-Hindrances, Effectiveness, Teacher Counsellor, Discipline, Narok County

\section{INTRODUCTION}

Discipline related issues have been at the forefront of education debates where most problems that students encounter are associated with their developmental changes that adolescent go through. During this period, adolescents undergo emotional and physical changes, emotional traumas and exhibit behavioural problems which are not only harmful for their health but are also in conflict with school expectation and social norms (Kinara, 2003). This being a trying period to their physical, emotional, psychological and academic development, the students try all sorts of adjustment mechanisms to get their needs fulfilled (Mangal, 2007).Troublesome adolescent stages have been documented as societal concerns for centuries, thus calling on parents, pastors, teachers, peers and significant others to assist students by providing effective guidance and counselling to forestall destruction, injuries and loss of life. Fieldman and Elliot (1990) posit that these behavioural challenges are associated with negative health, school administrators' failure, drug addiction, sexuality and associated infections, pregnancy, injury and death. The study concurs with their observation since drug and substance addiction has ruined the health, academic achievement and careers of many. Effective guidance and counselling should enable students deal with psychological problems that they may experience and make rational decisions on how to solve or cope with the challenges that they may encounter. Republic of Kenya (1999) recommends that guidance and counselling in educational institutions be an active and available service on daily basis to all students. 


\section{Objective of the Study}

To establish hindrances to effective delivery of guidance and counselling services towards enhancing discipline among secondary school students in Olokurto Division, Narok County, Kenya.

\section{Literature Review}

\subsection{Hindrances to Effective delivery of Guidance and Counselling for Enhancing Discipline}

Educational institutions, students, teachers, administrators and the entire school community look to the teacher counsellor especially when there is a crisis. Secondary school can be viewed as a time of both excitement and frustration and teacher counsellors find themselves in a situation where they are expected to provide counselling not only to the students but also to both teaching and support staff in addition to their teaching duties. Erford (2003) describes the role played byteacher counsellors as counselling, coordination and consultation. Thisstudy differs with Erford sincehis assertions on these roles did not provide a basis of serving all students since the training aspect including resources, facilities and funding of the guidance and counselling department were not catered for. As team players, teacher counsellors need to understand the importance of sharing responsibilities within the school system and collaborating with other teachers toensure there are no vacuums especially when they are assigned other duties apart from counselling.

Mutie and Ndambuki (2004) enumerate a number of challenges that teacher counsellors face, among them a shortage of trained personnel in this field thus the few available are overwhelmed by the teaching load and counselling duties were guidance and counselling department is considered a luxury. Reference books are rarely available in schools and there is therefore need for a clear policy in order to introduce and develop guidance and counselling programme in learning institutions with adequate funding and time allocation. Manduku (2002), recommends that teachers be encouraged and educated on the advantages of providing counselling services for discipline enhancement and propose that there be specific times and days when students can meet counsellors for guidance. This study however views his recommendations as limiting since emergencies were not catered for.

Manduku (2002) on the other hand posits that lack of or inadequacy of facilities was a major reason for the ineffective delivery of guidance and counselling services in Kenya's schools. He further argues that time, though immeasurable is an important resource that which was rarely available within the daily school routines. It therefore remains for the teacher counsellor to provide services as a crisis measure instead of an ongoing process. As noted earlier, teacher counsellors are overburdened because they have the same teaching load as their colleagues who are not actively involved in guidance and counselling. This proves futile to the development of the guidance and counselling programmes in learning institutions leading to the question; what will be the society's future morally without guidance and counselling to students with the increased breakdown of the family unit and availability of information through the social media?

Makewa (2008) notes that the teacher counsellors should keep abreast with knowledge and changing times since lack of reference books poses a threat to the teacher counsellors understanding of their students. The researcher concurs with Ndirangu (2000) who observes that teacher counsellors should go beyond the mare interest in guidance and counselling and equip themselves with relevant knowledge to be able to understand their students especially due to challenges posed by globalization and negative mass media where all manner of literature and information is really available. Kibui (2005) in his study on student attitude towards seeking counselling help suggests that peer and group counselling approaches be emphasized in schools. He posits that this could not only help to reach more students but also improve on their perception of the counselling process in order to arrest self-seeking behaviour and indiscipline cases. This study however notes that Kibui did not emphasize the importance of providing training to the peer counsellors to make them effectively handle students' concerns.Gitonga (1999) in an attempt to establish hindrances to effective delivery of guidance and counselling observes that one was lack of adequate time and noted that few schools had allocated time for guidance and counselling while Aduda (1995) highlights that workshops and seminars on counselling are few and far apart. Theresearchertakes cognizance that some of the hindrances to effective delivery of counselling services could be overcome by enabling the service providers gain more knowledge through collaboration with peers in other educational institutions. Students are part and parcel of the larger society away from schools and through collaboration with educational administrators and the community the number of violent movies and television programmes which the students watch could be limited by engaging them in good use of their leisure time.

\section{RESEARCHMETHODOLOGY}

The study was conducted in the 6 public secondary schools in Olokurto Division, Narok County with a target population of 861 comprised of form one to form four boys and girls students, 12 teacher counsellors and 6 deputy principals. A male and a female teacher counsellor purposively sampled from each school to ensure gender representation. Teacher counsellors participated in the study because they provide guidance and 
counselling services to students. Stratified sampling technique was employed to sample student and classes formed the strata. Kothari (2004) posits that stratified sampling yields more reliable and detailed data ensuring that no sub-population is omitted (Orodho, 2004). Simple random sampling technique was then employed to sample students in each stratum thus offer every student had an equal chance to participate in the study.

Descriptive survey design was employed in the study to establish the effectiveness of types of guidance and counselling employed to enhance discipline among secondary school students.Gay, Mills and Airasian (2009) observe that descriptive survey involves describing, analyzing and assessing attitudes, opinions towards individuals, organizations and procedures. Rubin and Babbie (2010) argue that surveys help make more generalized findings. This design was found appropriate since the study was seeking information concerning the current status on the effectiveness of guidance and counselling in enhancing discipline among students in Olokurto Division of Narok County. Questionnaires with multiple responses were administered to respondents yielding a reliability coefficient of $r=0.76$ in a test retest method thus accepted for the study. Qualitative data from the responses were organized thematically according to research objective and quantitative data analysis done to generate frequencies andpercentages with the aid of Statistical Package for Social Sciences (SPSS) version 20. Discussions were presented in tables, charts, graphs, means, percentages and frequencies.

\section{RESULTS AND DISCUSSIONS}

Demographic information of Respondents

Respondents of the study comprised male and female students, teacher counsellors and deputy principals.

\section{Students' Demographic Information}

The researcher sought to establish the population of the respondents according to gender in order to allocate an equitable sample representation to categories represented in the study. Figure 1 indicates that male students were more than female $78(61.40 \%)$ and $49(38.60 \%)$ respectively. Disparity indicates there were issues that negatively affected enrolment of students, especially girls. The researcher attributed the low enrolment of students to the inability of schools to retain them due to the numerous indiscipline cases such as pregnancies among girls, cultural practices in the community and the resultant poor academic results in Kenya Certificate of Secondary Education (KCSE).

\section{Gender of Students}

Figure 1 indicates low enrolment of female students which the study attributes to indiscipline cases reported (D.E.O.'s Office 2012). Retention rates were low due to girls' pregnancies while riots and strikes were a common occurrence.

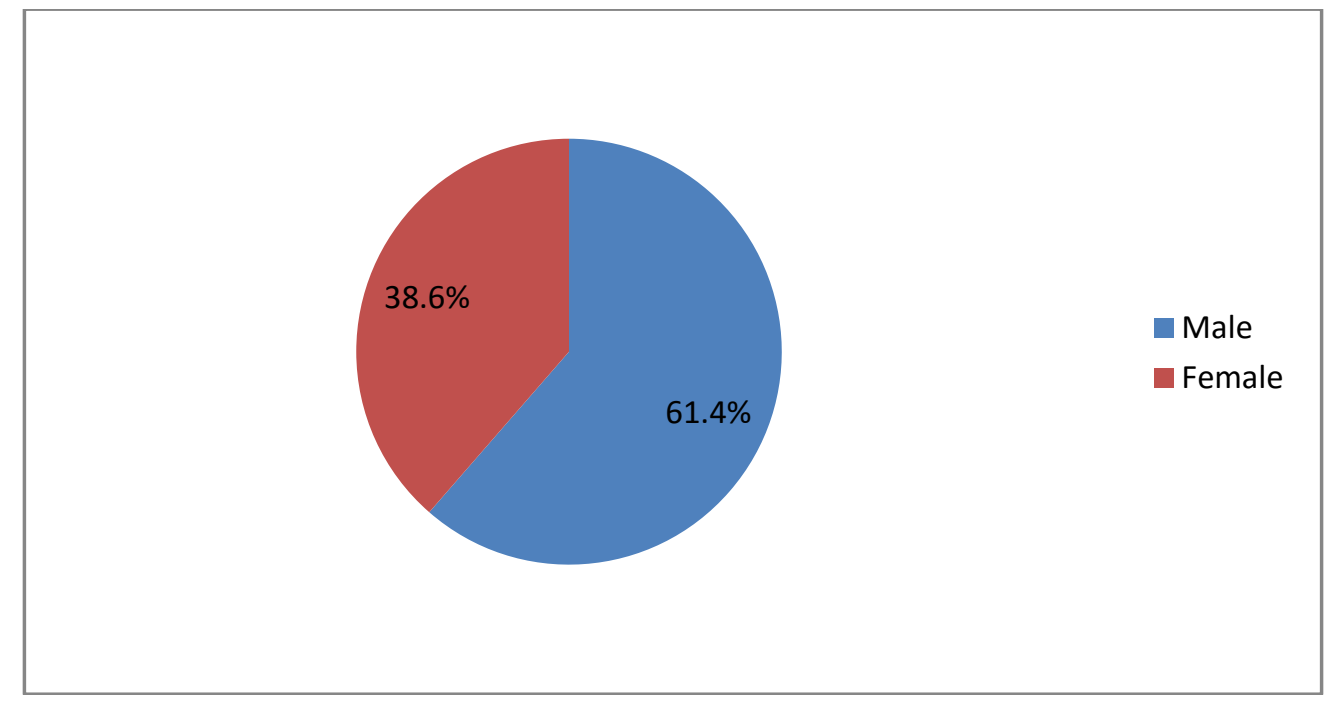

Figure 1: Gender of Students

\section{Age Brackets of Students}

Figure 2 indicates that $68.0 \%$ of the students were adolescents in the $16-19$ years age bracket with only $5.5 \%$ in the over 20 years - age bracket. The 13- 15 years age bracket were $26.5 \%$. Students within the indicated age brackets require continuous guidance to help them cope with challenges they encounter. Adolescence is 
considered to be a trying period especially for students in regard to their physical, emotional, psychological and academic development, thus a delicate stage (Mangal, 2007). In affirming Mangal's assertion, Wanjiku (2004) posits that rioting students in Makueni cried out that they required someone to listen to them while Wangombe (2008) posits that adolescents perceive themselves as adults in the society.

The researcher notes that adolescents require guidance and counselling to help them adjust to the different situations they may find themselves in.

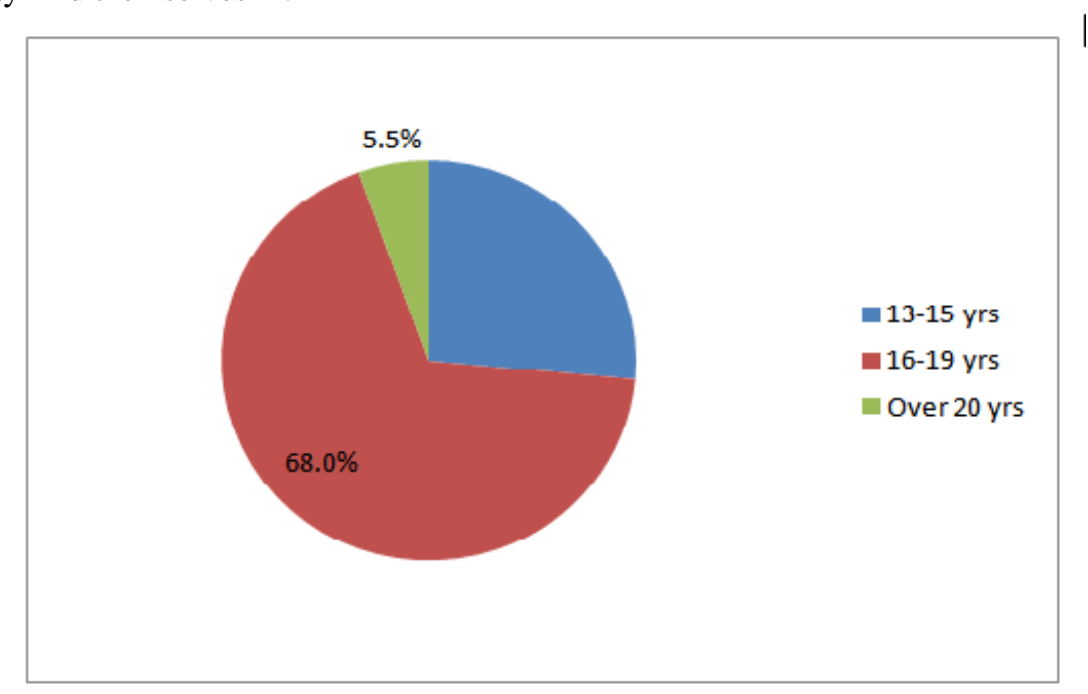

Figure 2: Age brackets of Students

\section{Class and School Category of Respondents}

Table 1 indicates that $93(73.2 \%)$ of the students were in mixed boarding schools compared to 34 $(26.8 \%)$ who were in day schools and thus in constant contact with their relatives. It further indicates that $30.7 \%$ of the respondents were in form one, $26.0 \%$ in form two, $24.4 \%$ in form three and $18.9 \%$. This means that most of the students were in the transitional stage: some exiting primary school life to join form one in new environments, thus requiring counselling to enable them adjust to new life away from their relatives.

From the students' demographic information, it is evident that there was high enrolment of students in form one and decreased as they moved towards fourth form. The number of female students had also decreased significantly from 111 students in form one to 63 in form four a decline of $43 \%$ for girls and $31 \%$ for boys. The researcher attributed the poor retention rate to indiscipline cases that include drug and substance abuse and cultural activities that lead to early marriage of girls while boys joined moranism (UNESCO, 2005).

$\underline{\text { Table } 1}$

Class and school category of Respondents

\begin{tabular}{lll}
\hline Class & \multicolumn{1}{c}{ Frequency } & Percentage \\
\hline Form 1 & 39 & 30.70 \\
Form 2 & 33 & 26.00 \\
Form 3 & 31 & 24.40 \\
Form 4 & 24 & 18.90 \\
\hline Total & 127 & $100 \%$ \\
\hline School Category & Frequency & Percentage \\
\hline Mixed Boarding & 93 & 73.20 \\
Mixed Day & 34 & 26.80 \\
Others & 0 & 0.00 \\
\hline Total & 127 & $100 \%$ \\
\hline
\end{tabular}

Teacher Counsellors' Demographic Information

Teacher counsellors' demographic information included age brackets, gender, and training levels school category.Figure 3 shows that $60 \%$ of the teacher counsellors were within $25-30$ age bracket while $20 \%$ of the counsellors were in the 31- 35 and the 36-40 years age brackets respectively. None of the teacher counsellors was over 40 years. The researcher observes that most of teacher counsellors had neither acquired the adequate knowledge, skills and techniques in guidance and counselling nor experience in the provision of counselling services due to their age and low training levels. The study concurs with Mutie and Ndambuki, (2004) and 
Republic of Kenya (1964) who advocate for the training of counsellors and inclusion of guidance and counselling in the teachers' training curriculum respectively.

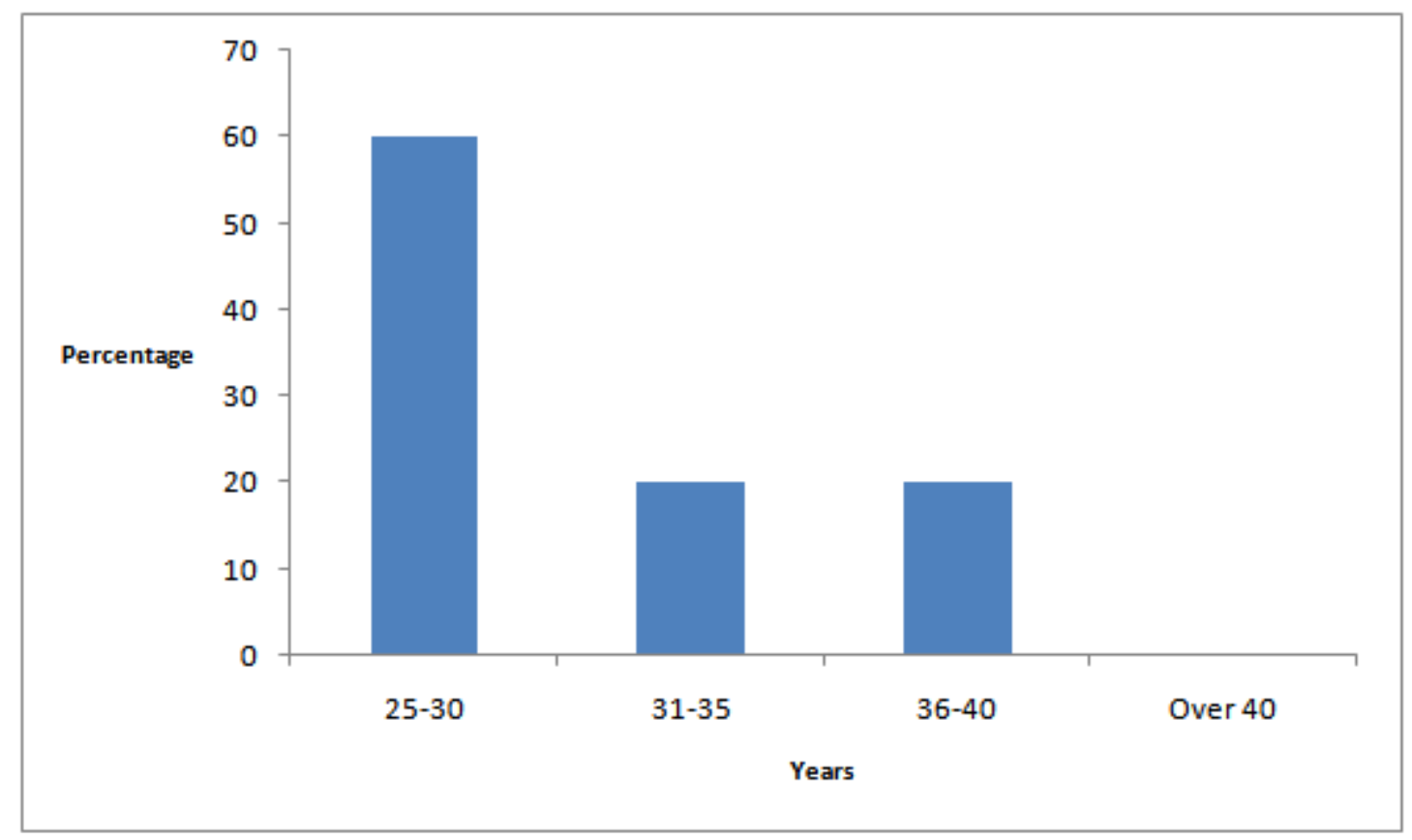

Figure 3: Age Brackets of Teacher Counsellors

\section{Gender of Teacher Counsellors}

Figure 4 shows that $60 \%$ of the counsellors were female while $40 \%$ were male teachers. Most students may not to receive counselling as frequently as they should due to gender disparity and population of teacher counsellors thus affecting discipline levels among students. This implied that the few male teachers available were not adequate to effectively offer counselling to students and this could compromise discipline among students especially in the area of study since cultural activities and traditional beliefs did not recognize the authority of women. For instance, moranism as a rite of passage was highly valued than education among boys while girls were married off at an early age (UNESCO, 2005).

Findings indicate that there was a shortage of guidance and counselling personnel in schools since the available counsellors could not effectively provide guidance and counselling services to 861 students in Olokurto division alongside attending to their teaching duties.

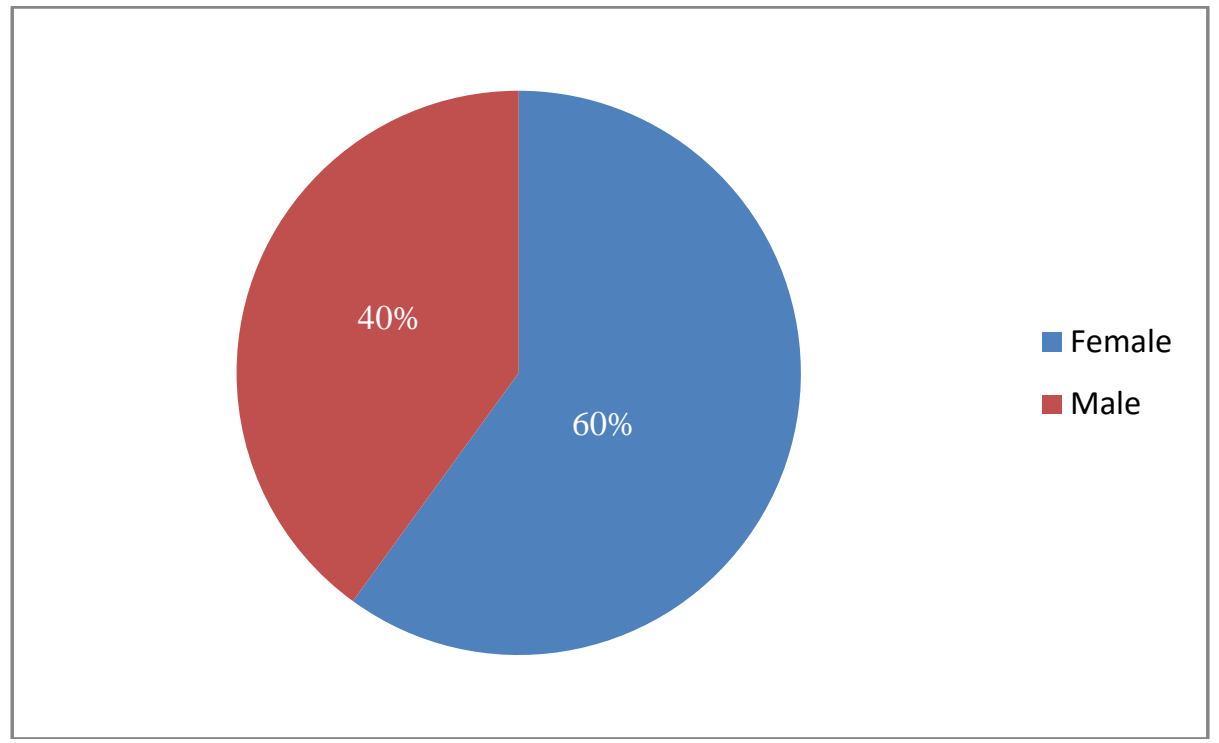

Figure 4: Gender of Teacher Counsellors

Training Levels of Teacher Counsellors 
Table 2 shows that $80 \%$ of teacher counsellors had received training at certificate level while $20 \%$ had received induction courses only. Percentages imply that most teacher counsellors had acquired basic knowledge in guidance and counselling. They however could not effectively address the issues and challenges that students encounter in their daily school life as they had not acquired adequate knowledge, skills and techniques.

Mangal (2007) describes adolescence as a trying period to the physical, emotional, psychological and academic development of students, thus they try all sorts of adjustment mechanisms to get their needs fulfilled. The study notes that students require continuous guidance and counselling to help them cope with challenging issues. This however was not happening as teacher counsellors had not acquired adequate training in counselling.

Table 2

Training Levels of Teacher Counsellors

Training Level in Guidance and Counselling Frequency Percentage

$\begin{array}{lcr}\text { Induction Course } & 2 & 20 \\ \text { Certificate } & 8 & 80 \\ \text { Other Levels } & 0 & 0\end{array}$

Total $10 \quad 100$

\section{Hindrances to Effective delivery of Guidance and Counselling}

The study sought to establish hindrances to effective delivery of guidance and counselling services towards enhancing discipline among secondary school students in Olokurto Division. Table 3 presents the teacher counsellors' responses on hindrances to effective delivery of guidance and counselling services. It shows that $60 \%$ of the teacher counsellors agreed that lack of or inadequate training for teachers lead to poor training of peer counsellors, hence ineffective delivery of guidance and counselling services. A further 50\% strongly agreed that workload and lack of policy framework $(70 \%)$ were hindrances to effective delivery of counselling services. The table also shows that $60 \%$ strongly agreed that interference from peers and parents and students unwillingness $50 \%$ were hindrances too. The study notes that shortage of personnel leads to overloading the few available leaving guidance and counselling services in the periphery, thus rendering delivery of counselling services ineffective. The study established there were no guidance and counselling rooms, files, reference books and cupboards for the safe storage of clients' information. Interference from peers and parents and negative mass media were also cited as hindrances to effective delivery of guidance and counselling services. A policy framework would guide school mangers in the provision of the required facilities and facilitate the training of teacher and peer counsellors in order to equip them with knowledge, skills and techniques for effective delivery of guidance and counselling services. The study concurs with Nyaga (2011) who posits that inadequate training of counselling personnel, limited resources and facilities were hindrances to effective delivery ofguidance and counselling services to students. Responses on negative mass media concur with the observation made by the taskforce on students' discipline and unrest in secondary schools (Republic of Kenya,2001). The study established that cases of indiscipline were the indicators of low training levels of guidance and counselling teachers or lack of it all together.Mohaty (2003) observes that effective guidance and counselling provides inspiration and encouragement to students and in time they are able to overcome indiscipline problems. The study established that there was a shortage of adequately trained teacher counsellors, lack of reference materials and training opportunities for counselling personnel, policy framework on the provision of guidance and counselling. The researcher observes that guidance and counselling is not only crucial for those students who deviate from the norms, but for all the students in a school setting as it facilitates behaviour change and enhances coping skills, promotes decision making, improves relationships and facilitates development of client's potential. For effective delivery of guidance and counselling services these constraints need to be addressed.

Table 3

Hindrances to Effective Delivery of Guidance and Counselling for Enhancing Discipline among Students

\begin{tabular}{|c|c|c|c|c|c|c|}
\hline \multirow[b]{2}{*}{ Statements } & \multicolumn{6}{|c|}{ Responses (Frequency and Percent) } \\
\hline & SA & A & NS & D & SD & TOTAL \\
\hline $\begin{array}{l}\text { Heavy work load in addition } \\
\text { to counselling duties }\end{array}$ & $4(40 \%)$ & $5(50 \%)$ & $0(0 \%)$ & $1(10 \%)$ & $0(0 \%)$ & $10(100 \%)$ \\
\hline
\end{tabular}

\begin{tabular}{lllllll}
\hline $\begin{array}{l}\text { Inadequate reference books } \\
\text { and facilities }\end{array}$ & $3(30 \%)$ & $5(50 \%)$ & $1(10 \%)$ & $1(10 \%)$ & $0(0 \%)$ & $10(100 \%)$
\end{tabular}


Hindrances To Effective Delivery Of Guidance And Counselling

\begin{tabular}{|c|c|c|c|c|c|c|}
\hline $\begin{array}{l}\text { Little or no cooperation } \\
\text { from other staff members }\end{array}$ & $1(10 \%)$ & $6(60 \%)$ & $0(0 \%)$ & $2(20 \%)$ & $1(10 \%)$ & $10(100 \%)$ \\
\hline $\begin{array}{l}\text { Students' negative } \\
\text { perception of guidance and } \\
\text { counselling }\end{array}$ & $1(10 \%)$ & $4(40 \%)$ & $(10 \%)$ & $3(30 \%)$ & $1(10 \%)$ & $10(100 \%)$ \\
\hline $\begin{array}{l}\text { Inadequate support from } \\
\text { theschool administration }\end{array}$ & $2(20 \%)$ & $3(30 \%)$ & $1(10 \%)$ & $2(20 \%)$ & $2(20 \%)$ & $10(100 \%)$ \\
\hline $\begin{array}{l}\text { Inadequately trained teacher } \\
\text { and peer counsellors to } \\
\text { provide counselling }\end{array}$ & $3(30 \%)$ & $6(60 \%)$ & $1(10 \%)$ & $0(0 \%)$ & $0(0 \%)$ & $10(100 \%)$ \\
\hline $\begin{array}{l}\text { Negative mass media and } \\
\text { pornographic literature }\end{array}$ & $4(40 \%)$ & $4(40 \%)$ & $0(0 \%)$ & $0(0 \%)$ & $2(20 \%)$ & $10(100 \%)$ \\
\hline $\begin{array}{l}\text { Lack of clear policy } \\
\text { guidelines on provisions of } \\
\text { guidance and counselling }\end{array}$ & $2(20 \%)$ & $7(70 \%)$ & $0(0 \%)$ & $1(10 \%)$ & $0(0 \%)$ & $10(100 \%)$ \\
\hline $\begin{array}{l}\text { Inadequate or no time } \\
\text { allocation for guidance and } \\
\text { counselling }\end{array}$ & $3(30 \%)$ & $3(30 \%)$ & $2(20 \%)$ & $1(10 \%)$ & $1(10 \%)$ & $10(100 \%)$ \\
\hline $\begin{array}{l}\text { Interference from peers and } \\
\text { parents }\end{array}$ & $2(20 \%)$ & $6(60 \%)$ & $2(20 \%)$ & $0(0 \%)$ & $0(0 \%)$ & $10(100 \%)$ \\
\hline $\begin{array}{ll}\text { Students unwilling } & \text { to } \\
\text { discuss their problems }\end{array}$ & $5(50 \%)$ & $5(50 \%)$ & $0(0 \%)$ & $0(0 \%)$ & $0(0 \%)$ & $10(100 \%)$ \\
\hline
\end{tabular}

\section{CONCLUSION}

The study established that there were constraints that hindered effective delivery of guidance and counselling services towards enhancing discipline among secondary school students. The teachers in charge of guidance and counselling are aware of their responsibilities in enhancing school discipline but are inadequately trained. Most schools don't take guidance and counselling seriously as indicated by lack of budgetary allocation, facilities and equipments such as storage rooms/cabinets, furniture and offices for conducting counselling services.Shortage of trained personnel, heavy workload and lack of resources were identified as major hindrances to effective delivery of counselling services. These hindrancesresulted in poor school discipline arising from inadequate training of counselling personnel, lack of support by school administration, inadequate funds and lack of vivid government policies on schools' guidance and counsellingprogrme. The findings of the study are a clear evidence of appropriateness of the objective under investigation.

\section{RECOMMENDATIONS}

The Ministry of Education should frequently organize workshops, seminars and courses for teacher counsellors in order to equip them with the necessary knowledge, skills and techniques to enable them provide effective guidance and counselling, thus enhance discipline among secondary school students. Resources, materials, reference books and facilities including policy guidelines should be provided to help students improve their behaviour positively, thus enhance discipline among students.

Unless the above recommendations were put in place, guidance and counselling as an alternative to other forms of managing students' issues may not effectively help enhance discipline in learning institutions. The results will be continued loss of more learning time, destruction of property, academic wastage and injury to human beings among other cases.

\section{REFERENCES}

[1] Aduda, D. (1995, Sept 10). Schools Provide Inadequate Counselling Services-Daily Nation.

[2] Erford, B.T. (2003) Transforming the School Counselling Profession, Upper Saddle River, New

[3] Jersey: Pearson Education, Inc.

[4] Gay,L. Mills, E.\&Airasian, P. (2009).Educational Research: Competences for Analysis and Application $\left(9^{\text {th }}\right.$ Ed) Upper Saddle River: Columbus Prentice Hall.

[5] Gitonga, P, (1999) A study of Secondary School Head Teachers' Attitudes towards Guidance and Counselling Programme in Meru Central District; Unpublished M Ed, Thesis; University of Nairobi.

[6] Kibue, F.N. (2005). Attitudes of Secondary School Students Towards Seeking Counselling Help:

[7] Case Study of Thika District Kenya; Unpublished M Ed. Thesis: Kenyatta University.

[8] Kinara, I. (2002). The Perception of Secondary School Students on the Importance of Guidance and Counselling in Kisii Central Nyanza: M. A. Thesis: University of Nairobi. 
[9] Kothari, C. (2004). Research Methodology Methods and Techniques ( $2^{\text {nd }}$ Revised Ed) New

[10] Delhi Willey Ltd.

[11] Makewa, P. W. (2008). Developing Youth; Nairobi, Uzima Publishing House.

[12] Manduku, J. (2002). Appraisal and Strengthening Guidance and Counselling Programmes in

[13] Schools: A case study of Nandi District Secondary Schools. M Ed. Thesis University of

[14] East Africa: Baraton.

[15] Mangal, S. K. (2007). Essentials of Educational Psychology: New Delhi Prentice Hallof India,

[16] Private Ltd

[17] Mbiti, D. (1989). Foundations of Schools Administration: Nairobi Kenya: Oxford University

a. Press.

[18] Mutie, E. \& Ndambuki, P. (2004). Guidance and Counselling for Schools and Colleges; Nairobi

[19] Ndirangu, J. (2000). Youth in Danger: A Handbook for Teachers, Students, Parents, Pastors and

[20] Community Workers: Nairobi Uzima.

[21] Nyaga, V. K. (2011) Effectiveness of Guidance and Counselling Services on University Students

[22] Development of Academic, Social and Personal Competencies: Comparative Study of

[23] Public and Private Universities in Kenya.Phd Thesis, Chuka University.

[24] Orodho, J. (2004). Essentials of Educational and Social Sciences Research Methods: Nairobi: Pauline's Publication Africa.

[25] Republic of Kenya(1964) Report of the Kenya Education Commission (Ominde report): Nairobi

[26] English Press.

[27] Republic of Kenya (1999) Totally Integrated Quality Education and Training (TIQET): Reportof

[28] the Commission of Inquiry into the Education System of Kenya, Nairobi: Government

[29] Printers.

[30] Republic of Kenya (2001) The Children's Act No. 8. Nairobi: Government Printers.

[31] Republic of Kenya (2001) Report of the Task Force on the Implementation of Free

Education: Nairobi, Jomo Kenyatta Foundation.

[32] Republic of Kenya (2001) Report of the Task Force on Student Discipline and Unrestin

[33] Secondary Schools: Government Printers, Nairobi.

[34] Rubin, A. \&Babbie, E. (2010) Essential Research Methods for Social Work: University of Texasat Austin Chapman University Nelson Education (Caanada).

[35] UNESCO. (2005). Challenges of Implementing Free Primary Education in Kenya: Nairobi.

[36] Wangombe, A. (2008). Adolescence Behaviour Problems Faced by School Administrators in

[37] Boys Boarding Secondary Schools, Kirinyaga District: Unpublished M.Ed. Thesis:

[38] Nairobi University. 